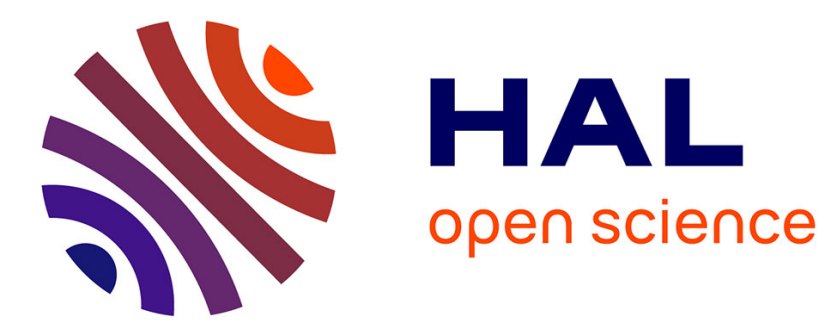

\title{
Production pattern of alkenones in the Mediterranean Sea
}

Yann Ternois, Marie-Alexandrine Sicre, Anne Boireau, Jean-Claude Marty, Juan-Carlos Miquel, Jean-Claude Marty

\section{- To cite this version:}

Yann Ternois, Marie-Alexandrine Sicre, Anne Boireau, Jean-Claude Marty, Juan-Carlos Miquel, et al. Production pattern of alkenones in the Mediterranean Sea. Geophysical Research Letters, 1996, 23 (22), pp.3171-3174. 10.1029/96GL02910 . hal-03594483

\section{HAL Id: hal-03594483 \\ https://hal.science/hal-03594483}

Submitted on 2 Mar 2022

HAL is a multi-disciplinary open access archive for the deposit and dissemination of scientific research documents, whether they are published or not. The documents may come from teaching and research institutions in France or abroad, or from public or private research centers.
L'archive ouverte pluridisciplinaire HAL, est destinée au dépôt et à la diffusion de documents scientifiques de niveau recherche, publiés ou non, émanant des établissements d'enseignement et de recherche français ou étrangers, des laboratoires publics ou privés. 


\title{
Production pattern of alkenones in the Mediterranean Sea
}

\author{
Yann Ternois ${ }^{1}$, Marie-Alexandrine Sicre $^{2}$, Anne Boireau ${ }^{1}$, Jean-Claude Marty ${ }^{3}$, and \\ Juan-Carlos Miquel $^{4}$
}

\begin{abstract}
Time-series of downward alkenone fluxes have been investigated at $200 \mathrm{~m}$ depth over a one year sediment trap experiment, in the Northwestern Mediterranean Sea. Alkenone flux maxima occurred in autumn and to a lesser extent in May, during the spring bloom. Temperature estimates calculated from the $U_{3}^{K^{\prime}}$ index revealed that alkenone producers preferentially develop in subsurface waters (at about $50 \mathrm{~m}$ ) in spring, whereas the autumn alkenone production occurred upper in the water column (around $30 \mathrm{~m}$ ). Examination of the core-top $U_{37}^{K}$ index values at various sites of the Northwestern Mediterranean basin, suggested that the spring bloom period do not significantly imprint the temperatures recorded in the sediments. The sedimentary temperature estimates would rather reflect annually integrated SST, with a major influence of the autumnal post-bloom development of the coccolithophores in the euphotic zone.
\end{abstract}

\section{Introduction}

Paleoclimatic studies focus on climate variability on a global scale. Such changes are evaluated using diverse approaches generally based on the ability of organisms to adjust and record changing environmental conditions either in their hard or soft components. One example of the flexibility of the organisms to develop an adaptative biochemistry are the alkenones. The within class distribution of this series of lipid constituents, encompassing $\mathrm{C}_{37}-\mathrm{C}_{39}$ di-, tri- and tetraunsaturated methyl and ethyl ketones, has been shown to be sensitive to growth temperature. Volkman et al. [1980] first reported alkenones and the related alkyl alkenoates in the marine coccolithophorid Emiliania huxleyi. Since then, other sources have been identified [e.g. Conte et al., 1994]. The degree of unsaturation of these compounds, the $U_{37}^{K^{\prime}}$ index, is related to surface water temperature [Marlowe, 1984; Brassell et al., 1986]. The term $\mathrm{U}_{37}^{\mathrm{K}^{\prime}}$ is defined as:

$$
U_{37}^{K^{\prime}}=\left(C_{372}\right) /\left\{\left(C_{372}\right)+\left(C_{373}\right)\right\}
$$

where $\left(C_{372}\right)$ and $\left(C_{373}\right)$ are the concentrations of the di- and

\footnotetext{
${ }^{1}$ Laboratorre de Physique et Chimie Marines, Université Pierre et Marıe Curıe, CNRS/INSU, 4 place Jussieu, 75252 Pans Cedex 05, France. (e-mail: ternois@ccr.jussieu.fr)

${ }^{2}$ Centre des Faibles Radioactivités, Laboratoire mixte CNRS-CEA, 91191 Gif sur Yvette Cedex, France (e-mail Mariealexandrine.Sicre@cfr.cnrs-gif.fr) (corresponding author)

${ }^{3}$ Laboratoire de Physique et Chimie Marnes, Unıversité Pierre et Marie Curie, CNRS/INSU, BP 8, 06230 Villefranche Sur Mer, France. (e-mail marty@ccrv.obs-vlfr.fr)

${ }^{4}$ IAEA Marıne Environment Laboratory, P O. Box 800, MC980I2 Monaco Cedex (e-mail: miquel@unice fr)

Copyright 1996 by the American Geophysical Union.

Paper number 96GL02910. 0094-8534/96/96GL-02910\$05.00
}

tri- unsaturated $C_{37}$ methyl alkenones, respectively. Results from culture experiments and oceanic waters have demonstrated a quasi-linear relationship between the temperature of alkenone production and the $U_{37}^{k}$ index in warm waters [Marlowe, 1984; Prahl and Wakeham, 1987; Prahl et al., 1988; Conte and Eglinton, 1993; Sikes and Volkman, 1993]. Recently, Ternois et al. [in press] calibrated the $\mathrm{U}_{37}^{\mathrm{K}^{\prime}}$ index versus in situ temperatures for the Mediterranean Sea. In this region, the paleo-temperature reconstruction based on foraminiferal assemblages is difficult, due to the fact that good modern analogs are hard to obtain for glacial fossil samples. Because of this limitation, alkenones provide an alternative to the reconstruction of paleo-temperatures.

Refinement of the alkenone-based sea surface temperature estimation methods requires a better understanding of the biomarker production cycle. The most comprehensive means to better constrain the use of alkenone unsaturation index is to acquire relevant data seeking to characterize the depth and timing of alkenone production in the modern ocean. This work presents alkenone data obtained from a one year sediment trap deployment at $200 \mathrm{~m}$ in the open Northwestern Mediterranean Sea conducted as part of the DYFAMED (France-JGOFs) timeseries program, and from surface sediments. The study's objective was to evaluate the applicability of $U_{37}^{K^{\prime}}$ for the reconstruction of paleo-temperatures in the Mediterranean Sea.

\section{Sampling and Methods}

Sediment traps were deployed at $200 \mathrm{~m}$ depth in the Ligurian Sea, from February 1989 to March 1990 (station 1, Figure 1) with some interruptions. This site is located $45 \mathrm{~km}$ offshore Nice in the Northwestern Mediterranean basin, in the Ligurian Sea. The water depth at the site is about $2300 \mathrm{~m}$. The sediment traps used (Technicap model PPS3) were cylindrical with a height of $1.9 \mathrm{~m}$, a height/width ratio of 2.5 in the cross cylindrical portion and a collection section of $0.125 \mathrm{~m}^{2}$. They were equipped with a pre-programmed 6 cup collector to collect six discrete samples with a 9 to 15 day sampling duration. Swimmers were removed from the samples before freezedrying.

Piston and box cores were collected from various sites in the Northwestern Mediterranean Sea (Figure 1) during two cruises aboard the Marion Dufresne R/V in 1990 and 1991 (Table 1). Sub-samples $(0-1 \mathrm{~cm}$ for $\mathrm{BC}$ samples and $5-6 \mathrm{~cm}$ for MD samples) were taken from each core using a stainless steel spatula, then wrapped in a aluminium foil and stored until analysis in the laboratory. Samples labelled as $\mathrm{BC}$ were frozen at $-18^{\circ} \mathrm{C}$ whereas those labelled as MD were stored at $4^{\circ} \mathrm{C}$. The surface sediment $(0-1 \mathrm{~cm})$ at station 1 was also collected. Methods for POC determinations are described in Miquel et al. [1994]. Organic carbon was measured in the sediment trap material by high temperature oxidization using a Heraeus CHN-O- Rapid analyzer. Carbonates were removed before analysis with $1 \mathrm{M} \mathrm{H}_{3} \mathrm{PO}_{4}$ and at least two replicates of each 


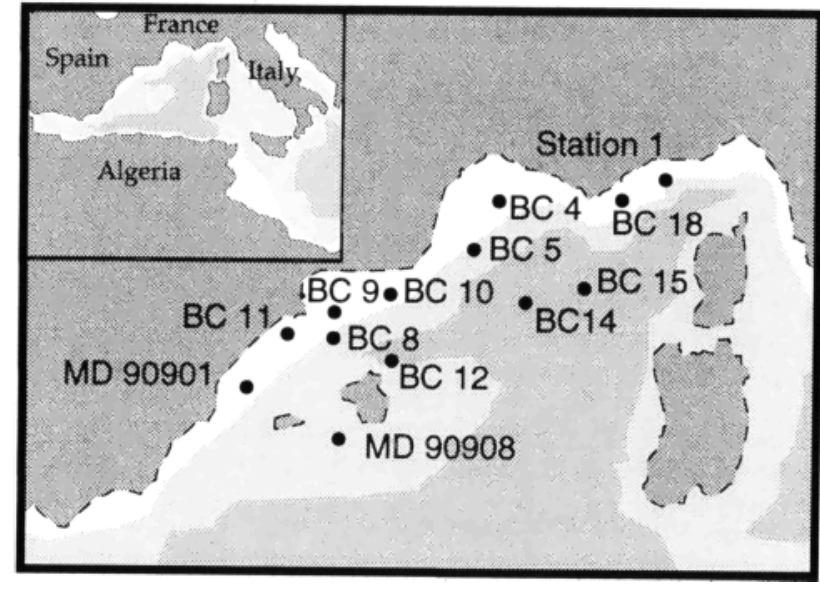

Figure 1. Map showing the sediment trap location (station 1) and sediment core locations in the Northwestern Mediterranean sea.

sample were run to reduce biais due to the potential sample heterogeneity.

Approximately $25 \mathrm{mg}$ of each freeze-dried sediment trap sample was extracted twice with $5 \mathrm{ml}$ of methylene chloride and a third time with $5 \mathrm{ml}$ of methanol. For each extraction the samples were ultrasonicated and centrifugated at 2000 rotations/min for 10 minutes. The total extracts were concentrated to just dryness using a rotary evaporator, and transferred to $4 \mathrm{ml}$ vials. Freeze-dried sediments were extracted following the same procedure as described above for sediment trap samples.

Lipid extracts from the sediment and sediment trap material were then partitioned into compound classes following the procedure decribed by Peltzer et al. [1984]. The fractions containing the alkenones were concentrated, transferred to vials and evaporated under a nitrogen stream. They were then analyzed on a Delsi DI 200 gas chromatograph equipped with a fused silica capillary column $(50 \mathrm{~m} \times 0.32 \mathrm{~mm}$ i.d. CP-Sil5, Chrompack) and a flame ionization detector. Helium was used as a carrier gas. The oven temperature was programmed from $50^{\circ} \mathrm{C}$ to $100^{\circ} \mathrm{C}$ at $25^{\circ} \mathrm{C}$. $\mathrm{min}^{-1}$ and from $100^{\circ} \mathrm{C}$ to $295^{\circ} \mathrm{C}$ at $5^{\circ} \mathrm{C}$. $\min ^{-\mathrm{r}}$. Quantitation of alkenones was achieved using $\alpha$ cholestane, added to the sample prior to injection. Compounds were quantified using the Apex $\mathrm{PC}$ based chromatograph software. The accuracy of alkenone concentration determination was about $10 \%$.

\section{Results and Discussion}

\section{Sediment Trap Data}

Figures 2a-b show the temporal variability of organic carbon and alkenone fluxes at $200 \mathrm{~m}$ depth from February 1989 to March 1990, in the Ligurian Sea. Estimated temperatures, calculated from the calibration established for the Mediterranean waters by Ternois et al. [in press] ( $\mathrm{U}_{37}^{\mathrm{K}^{\prime}}$ $=0.041 \mathrm{~T}-0.21, r^{2}=0.97, n=20$ ), are also reported in figure $2 b$. From this record, alkenone production appears strongly seasonal. The maximum alkenone flux occurred in October. A smaller production maximum occurred during the last two weeks of May which coincided with the spring bloom period. Estimated $U_{37}^{R^{*}}$ temperatures were approximately $17^{\circ} \mathrm{C}$ in

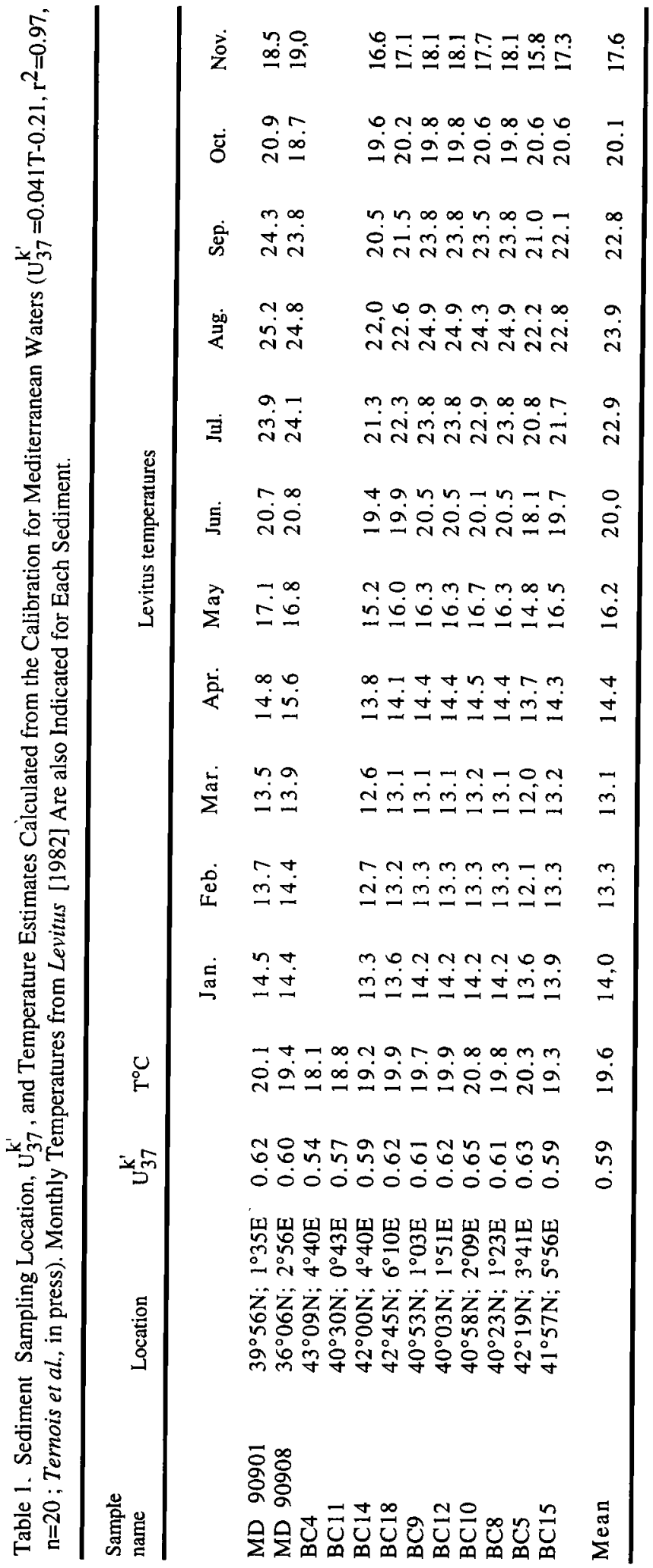



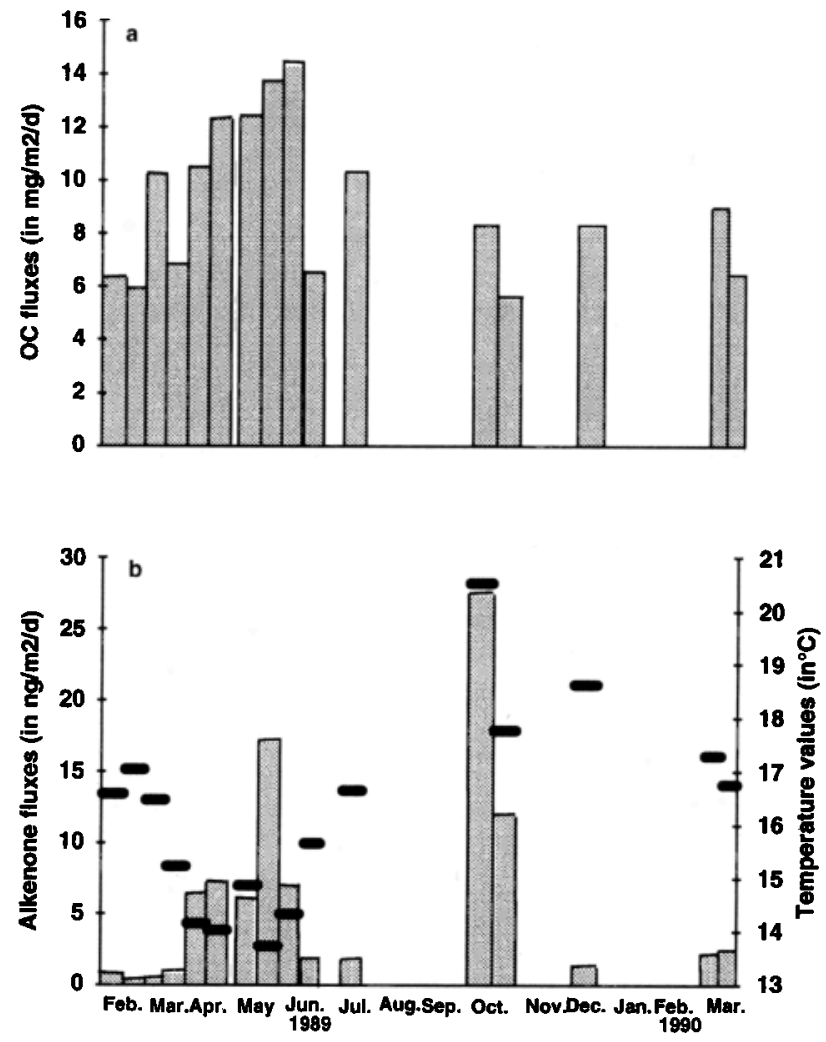

Figure 2. Temporal variations of (a) the organic carbon flux, (b) alkenone fluxes. Estimated temperatures calculated from the calibration equation: $\mathrm{U}_{37}^{\mathrm{K}}=0.041 \mathrm{~T}-0.21, \mathrm{r}^{2}=0.97$, $\mathrm{n}=20$ [Ternois et al., in press] are also reported (thick dashes).

February and decreased during April, May and June, to about $14^{\circ} \mathrm{C}$. These values were lower than expected from surface water temperature in the spring months (figure 3 ). This indicates a deepening of the depth distribution of alkenoneproducing phytoplankton [Ternois et al., in press], 'consistent with the similar production patterns observed by Prahl et al. [1993] in the NE Pacific. Alkenone-producers live in the upper euphotic zone when nutrients are not limited. As primary production continues in spring, surface waters become depleted in nutrients and alkenone producers then grow in subsurface waters where sufficient nutrients are available. In summer, alkenone fluxes decline due to the nutrient depletion in the euphotic zone, as the thermocline builts up. In October the nutrient supply restored by regeneration, and possibly also the deepening of the mixing layer replenish surface waters. Alkenone production rises again and reaches its highest value. Temperature estimates derived from $U_{37}^{K^{\prime}}$ are those measured in surface waters at this time of the year, around $18-19^{\circ} \mathrm{C}$ (figure 3), indicating that alkenone production predominantly occurred in surface waters again. This inference is supported by the vertical profiles of alkenones in the water column [Ternois et al., in press].

Our results suggest that the production pattern of alkenone producers may differ from that of the overall primary production in the Mediterranean Sea. However this feature needs to be confirmed by longer-term trap series to ensure that high fall fluxes are recurrent events of the coccolithophore production cycle.

\section{Core Top Data}

The occurrence of alkenones in sediments demonstrates that they can partly survive degradation. Although alkenones may experience some degradation, evidence indicates that the $U_{37}^{K^{\prime}}$ values remain unaltered [Prahl et al., 1989; Madureira et al., 1995]. Temperature estimates were calculated from the $U_{37}^{K^{\prime}}$ values measured in each core-top using the Mediterranean calibration established by Ternois et al. [in press]. Temperature estimation accuracy is $\pm 0.44^{\circ} \mathrm{C}$. Temperature values ranged from $18.1^{\circ} \mathrm{C}$ to $20.8^{\circ} \mathrm{C}\left(\Delta \mathrm{T}=2.7^{\circ} \mathrm{C}\right.$, $\mathrm{T}_{\text {mean }}=19.6^{\circ} \mathrm{C}$ ) (Table 1). They were compared to monthly sea surface water temperatures [Levitus, 1982] at each core-top location to determine, site by site, which season is most closely recorded by the sediment signal (Table 1). Except for two samples (BC4 and $\mathrm{BC} 11$ ) for which data were not available, temperature estimates are similar to those encountered in surface waters in October and/or June. As discussed above, time-series of sediment trap data have shown that in spring alkenones were produced deeper in the water column, recording temperatures comprised between 14 and $15^{\circ} \mathrm{C}$. If so, the alkenone exported from the euphotic zone at that time can not account for the observed temperature estimates derived from sedimentary $U_{37}^{K^{\prime}}$. In contrast, temperatures reconstructed from the sediment traps in October are closer to sedimentary $\mathrm{U}_{37}^{\mathrm{K}^{\prime}}$ index, for each site (except for $\mathrm{BC} 15$ ). This result agrees with the large autumn production observed in the trap series. At this time of the year, the alkenone flux is higher and therefore may represent a major input to the marine sediment which would more significantly imprint the $\mathrm{U}_{37}^{\mathrm{K}^{\prime}}$ values preserved in the sediments, than low flux periods. However, we cannot rule out the possiblity that sedimentary $\mathrm{U}_{37}^{\mathrm{K}^{\prime}}$ may also reflect annually-integrated SST. Mean annual SST, calculated at station 1 based on $U_{37}^{K^{*}}$ measurements in each cup of the trap weighted for alkenone fluxes, was estimated to $17.3^{\circ} \mathrm{C}$. This value was by $1^{\circ} \mathrm{C}$ lower than the estimated "production" temperature derived from the $\mathrm{U}_{37}^{\mathrm{K}^{\prime}}$ measured in surficial sediment at this site $\left(\mathrm{T}=18.3^{\circ} \mathrm{C}\right)$. This may be primarily explained by the fact that the sediment trap record is incomplete and, noticeably, that the summer months, characterized by higher SST, are missing in the sediment trap record. This would lead to underestimate the annually

\section{Composite data of potential temperatures (1991-1994)}

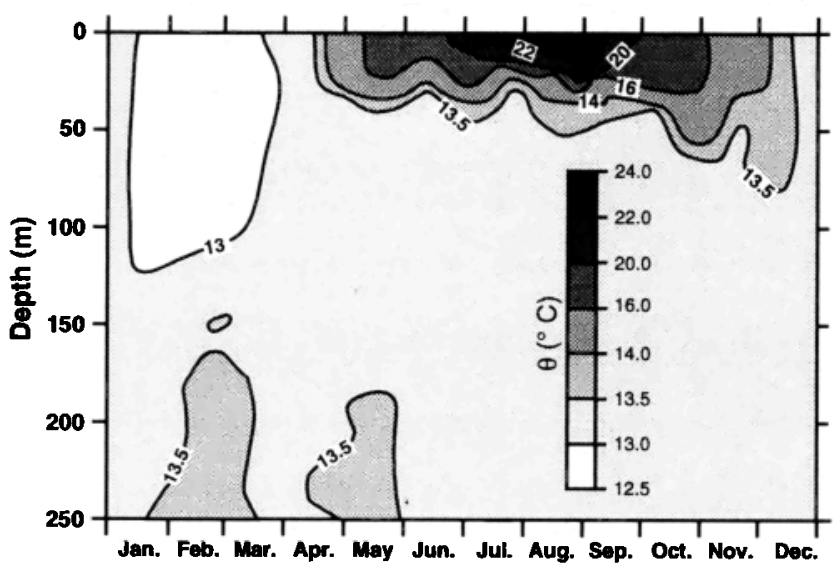

Figure 3. Composite of monthly potential temperatures (in ${ }^{\circ} \mathrm{C}$ ) from 1991 to 1994 in the first $250 \mathrm{~m}$ depth, at the sediment trap site, station 1 . 
integrated temperature signal. Similar results were obtained when comparing SST derived from the core-top $U_{37}^{K^{\prime}}$ with those calculated from Levitus Atlas monthly temperatures weighted by alkenone fluxes from the sediment traps. SST derived from core-top $\mathrm{U}_{37}^{\mathrm{K}^{\prime}}$ values were also $1^{\circ} \mathrm{C}$ higher. Although other reasons may be invoked [Prahl et al., 1993], such as the possibility of a more efficient remineralization during high production periods, in the water column and/or sediment, the limitation of the sediment trap sampling do not allow further discussion on the observed temperature offset.

\section{Conclusions}

The comparison of alkenone temperature estimates derived from surface sediment with sediment trap data and water column temperature profiles in the euphotic zone indicated that the sedimentary alkenone temperature signal does not reflect spring bloom SST but rather annual integrated SST with a strong imprint of fall temperatures, when coccolithophore production is more important. Annually integrated temperatures calculated from the sediment trap data were $1^{\circ} \mathrm{C}$ lower than those recorded in surficial sediments at station 1 and other sites of the Northwestern Mediterranean basin, possibily due to the summer months missing in the trap record. Our data suggest that inferences based on core-top $U_{37}^{R^{\prime}}$ values must consider the seasonality and depth of the alkenone production. This study points out the applicability of alkenones in paleoclimatology and paleoceanography, and emphasizes the needs to better constrain this tool by further investigations on interannual variability of the coccolithophore production.

Acknowledgments. The IAEA Marine Environment Laboratory operates under the agreement between the International Atomic Energy Agency and the Government of the Principality of Monaco.

\section{References}

Brassell, S.C., G. Eglinton, I.T. Marlowe, U. Pflaumann, and M. Sarnthein, Molecular stratigraphy: a new tool for climatic assessment, Nature, 320, 129-133, 1986.

Conte, M.H, and $G$ Eglinton, Alkenone and alkenoate distributıons within the euphotic zone of the eastern North Atlantic correlation with production temperature, Deep-Sea Res., 40, 1935-1961, 1993

Conte, M.H, J.K. Volkman, and G. Eglınton, Lipid biomarkers of the Haptophyta, in The Haptophyte Algae, 5I, edited by J.C. Green and B.S.C. Leadbeater, pp. 351-377, Clarendon Press, Oxford, 1994.

Levitus, S., Climatological Atlus of the World Ocean, Natl. Oceanic and Atmos. Admin. Rockville, Md., 1982.

Madureira, L.A S., M.H. Conte, and G. Eglinton, Early diagenesis of lipid biomarker compounds in North Atlantic sediments, Paleoceanography, 10(3), 627-642, 1995.

Marlowe, IT., Lipids as paleoclimatic indicators, $\mathrm{PhD}$ thesis, $273 \mathrm{pp}$. University of Bristol, 1984

Miquel, J.C., S.W. Fowler, J. La Rosa, and P. Buat-Menard, Dynamics of the downward flux of particles and carbon in the open Northwestern Mediterranean Sea, Deep Sea Res., 4I, 243-261, 1994

Peltzer, E.T., J.B Alford, and R.B. Gagosian, Methodology for sampling and analysis of lipids in aerosols from the remote marine atmosphere, Tech. Rep.WHOI-84-9, 104 pp, Woods Hole Oceanographic Institution, Woods Hole, Mass., 1984

Prahl, F G., and S.G. Wakeham, Calibration of unsaturation patterns in long-chain ketone compositions for paleotemperature assessment, Nature, 330, 367-369, 1987.

Prahl, F G., L.A. Muehlhausen, and D.L Zahnle, Further evaluation of long-chain alkenones as indicators of paleoceanographic conditions, Geochim. Casmochim. Acta, 52, 2303-2310, 1988.

Prahl, F.G., G.J. de Lange., M. Lyle, and M.A. Sparrow, Postdepositional stability of long-chain alkenones under contrasting redox conditions, Nature, 34I, 434-437, 1989.

Prahl, F.G., R.B Collier, J. Dymond, M. Lyle, and M.A. Sparrow, A biomarker perspective on prymnesiophyte productivity in the Northeast Pacific Ocean, Deep-Sea Res. ,40, 2061-2076, 1993.

Sikes, E.L., and J.K. Volkman, Calibration of alkenone unsaturation ratıos $\left(\mathrm{U}_{37}^{k}\right)$ for paleotemperature estimation in cold polar waters, Geochim. Cosmochim. Acta, 57, 1883-1889, 1993.

Ternors, Y., M-A Sicre, A Boireau, M.H. Conte, and G. Eglinton, Evaluation of long-chain alkenones as paleo-temperature indicators in the Mediterranean Sea, Deep-Sea Res., in press, 1996.

Volkman, J.K., G. Eglinton, E.D.S. Corner, and J.R. Sargent, Novel unsaturated straight-chain $\mathrm{C}_{37}-\mathrm{C}_{39}$ methyl and ethyl ketones in marine sediments and a coccolithophorid Emiliana huxleyi, in Advances in Organic Geochemistry 1979, edited by Douglas A.G. and Maxwell J.R., pp. 219-227, Pergamon Press, Oxford, 1980.

(Received March 27, 1996; revised July 23, 1996; accepted September 4, 1996) 